\title{
Endosomal Escape Pathways for Non-Viral Nucleic Acid Delivery Systems
}

Wanling Liang and Jenny K. W. Lam

Additional information is available at the end of the chapter

http://dx.doi.org/10.5772/46006

\section{Introduction}

Nucleic acids, including plasmid DNA (pDNA) and small interfering RNA (siRNA), are potential therapeutic macromolecules that have been widely explored for the treatment or prevention of various human diseases in the last three decades. pDNA encoding a therapeutic gene sequence can be introduced into the nuclei of the target cells to express functional proteins through transcription and translation in order to produce therapeutic effects. The therapeutic scope of pDNA includes a vast number of diseases, such as cancers (El-Aneed 2004; Yamamoto and Curiel 2005; Johnson, Morgan et al. 2009), genetic disorders (Gaspar, Parsley et al. 2004; Aiuti, Cattaneo et al. 2009; Griesenbach and Alton 2009), infections (Yu, Poeschla et al. 1994; Hashiba, Suzuki et al. 2001; Cull, Bartlett et al. 2002) and cardiovascular diseases (Stewart, Hilton et al. 2006; Vinge, Raake et al. 2008; Henry and Satran 2012). To date, over 1600 gene therapy clinical trials have been initiated (http://www.abedia.com/wiley/phases.php; Edelstein, Abedi et al. 2007). Apart from pDNA, siRNA has recently been intensively studied as a new therapeutic agent. RNA interference (RNAi) was discovered by Fire and colleagues based on the study of $C$. elegans (Fire, Xu et al. 1998). According to their observation, double-stranded RNA (dsRNA) mediates potent and specific silencing of homologous genes. Elbashir et al. demonstrated that the sequencespecific mediator of RNAi is 21-23-nucleotide siRNA produced from the cleavage of longer dsRNA by ribonuclease III (Elbashir, Lendeckel et al. 2001). Since then the mechanism of RNAi has been revealed and reviewed in many publications (Bernstein, Caudy et al. 2001; Hammond, Boettcher et al. 2001; Ketting, Fischer et al. 2001; Hannon and Rossi 2004; Mello and Conte 2004). Briefly, siRNA interacts with the RNA-induced silencing complex (RISC) located in the cell cytoplasm and subsequently induces cleavage of mRNA with complementary sequences, thereby inhibiting the translation of a specific protein. Soon after RNAi was discovered to work in mammalian cells (Sui, Soohoo et al. 2002), it quickly emerged as a new therapeutic strategy to suppress the expression of disease-causing gene. 
So far, the therapeutic potential of siRNA has been demonstrated successfully both in vitro and in vivo (Shim and Kwon 2010) while a number of siRNA-based therapy clinical trials have been initiated, including therapeutics directed against inherited skin disorder (Leachman, Hickerson et al. 2009), solid tumor (Davis, Zuckerman et al. 2010), respiratory syncytial virus (RSV) infection (DeVincenzo, Cehelsky et al. 2008; DeVincenzo, LambkinWilliams et al. 2010) and age-related macular degeneration (AMD) (Kaiser, Symons et al. 2010). Until now however, there are no pDNA or siRNA-based therapeutic products approved by the FDA; the lack of an efficient and safe delivery system being the major hurdle to limit the clinical application of nucleic acids.

\subsection{Nucleic acid delivery}

In terms of delivery, therapeutic nucleic acids must be transported to their target sites (nucleus for pDNA or RISC in the cytoplasm for siRNA) before producing their biological effects. A delivery system must overcome a series of extracellular and intracellular barriers (Sanders, Rudolph et al. 2009). Nucleic acids are susceptible to endogenous nuclease degradation in the serum and the half-life of unprotected nucleic acids is approximately 10 minutes in mouse whole blood (Kawabata, Takakura et al. 1995). In addition, nucleic acids are negatively charged, hydrophilic macromolecules and are incapable of crossing the plasma membrane unassisted (Khalil, Kogure et al. 2006; Lam, Liang et al. 2012). To achieve successful transfection, an effective nucleic acid delivery system must be able to perform several functions: (i) bind or condense nucleic acids into nanoparticles, (ii) protect nucleic acids from enzymatic degradation, (iii) promote cellular uptake, (iv) release nucleic acids into the cytoplasm, (v) promote nuclear entry (for pDNA delivery) (Bally, Harvie et al. 1999). The use of a carrier system such as cationic polymers (Laga, Carlisle et al. 2012), lipids/ liposomes (Ewert, Zidovska et al. 2010) or peptides (Hassane, Saleh et al. 2010) is the most commonly investigated delivery method for clinical purposes. It was soon found that the transfection efficiency of nucleic acid delivery systems is correlated to not only the level of cellular uptake but also with their ability to escape from endosomal compartments (El Ouahabi, Thiry et al. 1997). Some nucleic acid delivery systems successfully attain high cellular uptake, but fail to achieve good transfection, partly due to their deficiency of endosomolytic property (Medina-Kauwe, Xie et al. 2005). Therefore additional measures must be adopted to promote endosomal escape of the nucleic acid delivery system.

\subsection{Intracellular delivery}

Viral vectors are known for their high efficiency in transferring nucleic acids into host cells as they have evolved sophisticated endosomal releasing mechanisms which take advantage of the acidic environment inside the endosomes (Cho, Kim et al. 2003). However, the clinical application of viral vectors is limited because of the strong immunogenicity and potential fatal adverse effects (Baum, Düllmann et al. 2003; Hacein-Bey-Abina, von Kalle et al. 2003; Raper, Chirmule et al. 2003; Hacein-Bey-Abina, Garrigue et al. 2008). Compared with viral vectors, non-viral vectors offer advantages of relatively low toxicity and immune response. 
However, the delivery efficiency of non-viral vectors is generally poor (Pérez-Martínez, Guerra et al. 2011). To enhance transfection efficiency, substantial efforts have been made to elicit effective endosomal escape. Endocytosis is the major route of cellular entry for nonviral nucleic acid delivery (Khalil, Kogure et al. 2006; Pathak, Patnaik et al. 2009). A number of endocytosis pathways are known to be involved in the uptake of non-viral gene delivery systems, including clathrin-mediated endocytosis, caveolae-mediated endocytosis, macropinocytosis and phagocytosis. However the contribution of each pathway in the internalization of non-viral vectors is not clearly understood due to the diversity of carriers (Morille, Passirani et al. 2008).

After non-viral delivery systems enter into the cells via endocytosis they are immediately transported into the endocytic vesicles. Initially, the delivery vectors are trapped in the early endosomes where the $\mathrm{pH}$ drops from neutral to around $\mathrm{pH}$ 6. Early endosomes may fuse with sorting endosomes in which the internalized content can be recycled back to the membrane and transported out of the cell by exocytosis. More often, the delivery systems are trafficked to late endosomes which are rapidly acidified to $\mathrm{pH} 5-6$ by the action of the membrane-bound ATPase proton-pump. Subsequently, the late endosomes fuse with lysosomes concomitant with a further $\mathrm{pH}$ reduction to approximately $\mathrm{pH} 4.5$ and the existence of various degradative enzymes. The low $\mathrm{pH}$ of lysosomes facilitates substrate denaturation and aids lysosomal hydrolases, most of which operate optimally in the range of pH 4.5-5.5 (Mellman, Fuchs et al. 1986). Nucleic acids that fail to be released from these acidic vesicles will ultimately be degraded (Pack, Hoffman et al. 2005; Khalil, Kogure et al. 2006). Therefore, the $\mathrm{pH}$ reduction and the enzymatic degradation process in endosomes/lysosomes is an efficiency-limiting step for successful nucleic acid delivery (Whitehead, Langer et al. 2009). Ideal vectors should release their contents from these acidic compartments at an early stage to prevent the fate of lysosomal destruction.

\subsection{Endosomal escape}

Various approaches have been attempted to promote early endosomal escape of non-viral gene delivery vehicles and many hypotheses have been suggested to explain these processes. The proton sponge hypothesis has been proposed for cationic polymers such as polyethylenimine (PEI) (Boussif, Lezoualc'h et al. 1995; Behr 1997) and polyamidoamine (PAMAM) dendrimers (Zhou, Wu et al. 2006). For cationic-lipid based delivery systems, the flip-flop mechanism was proposed for their endosomal escape mechanism (Xu and Szoka Jr 1996). Cell-penetrating peptides (CPPs) represent another category of promising candidates as non-viral nucleic acid carriers, for example TAT (Torchilin 2008), pep analogues (Gros, Deshayes et al. 2006), GALA (Li, Nicol et al. 2004), MPG (Simeoni, Morris et al. 2003), CADY (Konate, Crombez et al. 2010) and LAH4 derivatives (Lam, Liang et al. 2012) etc. Their mechanisms of promoting endosomal release are still controversial; it has been suggested that the opening of transient pores in the lipid bilayer of endosome is involved (Melikov and Chernomordik 2005), alternatively CPPs may undergo conformational changes in response to the acidification inside the endosomes, leading to destabilization of the endosomal 
membrane bilayer (Kichler, Mason et al. 2006). Last but not least, photochemical internalization (PCI) is a technique that aims to improve endosomal release. A photosensitizer is localized in the endosomal membrane and destabilizes the membrane upon illumination, triggering the release of endosomal content into cytosol (Berg, Kristian Selbo et al. 1999; Endoh and Ohtsuki 2009).

In order to achieve high levels of transfection, different strategies have been employed to protect nucleic acids from degradation inside endosomes and facilitate their early release from acidic compartments into the cytosol. Various endosomal escape mechanisms of nonviral vectors as well as the endosomolytic reagents which can promote endosomal release are introduced in detail here.

\section{Strategies of non-viral vectors for endosomal escape}

\subsection{The 'proton sponge' hypotheses (pH-buffering effect)}

There is a long history regarding the application of cationic polymers to mediate nucleic acid transfer into cells. Cationic polymers can form polyplexes with nucleic acids through electrostatic interaction. Polylysine (PLL) was one of the first cationic polymers investigated for nucleic acid delivery although it failed to display desirable transfection efficiency (Pack, Hoffman et al. 2005). Later, it was discovered that polymers that contain protonable residues at physiological $\mathrm{pH}$, like polyamidoamine (PAMAM) dendrimers and lipopolyamines (Remy, Sirlin et al. 1994) successfully achieve high transfection efficiency in contrast to PLL, which does not possess buffering capacity because of the presence of the strongly charged amino groups (Haensler and Szoka Jr 1993). This pH-buffering property was soon shown to be an important feature of cationic polymers that may induce endosomal disruption and prevent nucleic acids from lysosomal degradation.

Polyethylenimine (PEI) is a synthetic cationic polymer with high amine density and various applications (Godbey, Wu et al. 1999). In 1995, Boussif et al. investigated the DNA delivery potential of PEI and found that this polymer can effectively transfer luciferase reporter gene into a variety of cell lines and primary cells (Boussif, Lezoualc'h et al. 1995). The remarkable nucleic acid-delivery ability of PEI was attributed to a "proton sponge" effect in which the extensive buffering capacity of PEI serves a dual purpose: (i) to inhibit the activity of lysosomal nuclease and (ii) to change the osmolarity of acidic vesicles resulting in endosomal swelling and rupture.

The 'proton sponge' phenomenon has been observed in certain cationic polymers with a high $\mathrm{pH}$ buffering capability over a wide $\mathrm{pH}$ range. These polymers usually contain protonatable secondary and/or tertiary amine groups with $\mathrm{pKa}$ close to endosomal/lysosomal $\mathrm{pH}$. During the maturation of endosomes, the membrane-bound ATPase proton pumps actively translocate protons from the cytosol into the endosomes, leading to the acidification of endosomal compartments and activation of hydrolytic enzymes. At this stage, polymers with the 'proton sponge' property will become protonated and resist the acidification of endosomes (fig. 1). As a result, more protons will be 
continuously pumped into the endosomes with the attempt to lower the $\mathrm{pH}$. The proton pumping action is followed by passive entry of chloride ions, increasing ionic concentration and leading to water influx. Eventually the osmotic pressure causes swelling and rupture of endosomes, releasing their contents to the cytosol (Boussif, Lezoualc'h et al. 1995; Behr 1997; Pack, Hoffman et al. 2005). Sonawane et al. (Sonawane, Szoka Jr et al. 2003) tested this hypothesis by studying the concentration of chloride ions, $\mathrm{pH}$ and the volume of endosomes after internalization of polyplexes composed of pDNA, non-buffering PLL as well as the highly buffering PEI and PAMAM. Significant chloride ion accumulation, volume expansion and membrane lysis were detected in PEI and PAMAM containing endosomes but not the ones with PLL. This finding provides direct support for the proton sponge hypothesis and a rationale for the design of polymer-based nucleic acid delivery vectors.
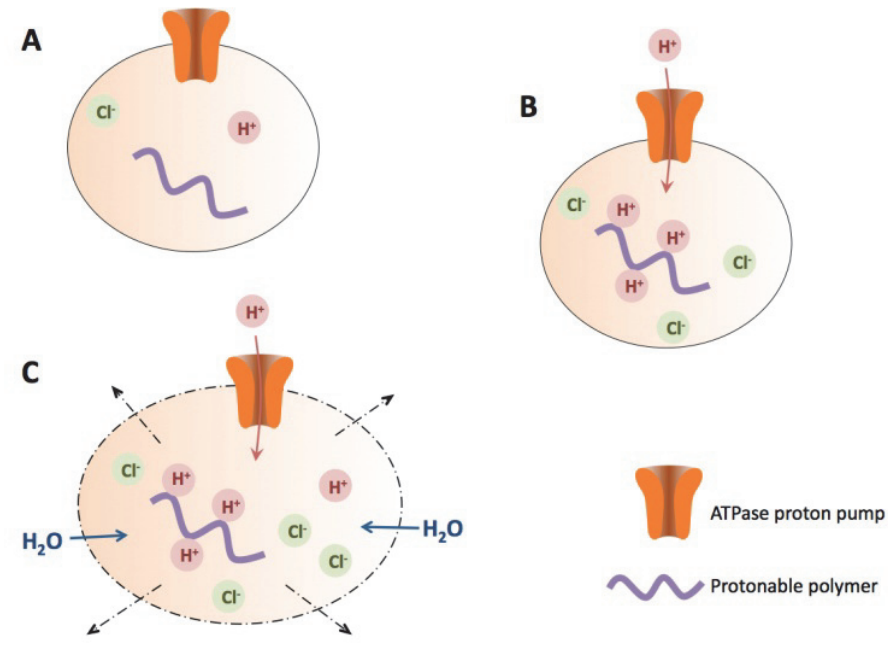

Figure 1. The 'proton sponge' hypotheses (pH-buffering effect). (A) Polyplexes enter cell via endocytosis and are trapped in endosomes. (B) The membrane bound ATPase proton pumps actively translocate protons into endosomes. Polymers become protonated and resist the acidification of endosomes. Hence more protons will be pumped into the endosomes continuously to lower the $\mathrm{pH}$.

(C) The proton pumping action is followed by passive chloride ions entry, increasing ionic concentration and hence water influx. High osmotic pressure causes the swelling and rupture of endosomes, releasing their contents to cytosol.

To date, PEI has been demonstrated to transfect nucleic acids successfully into a broad range of cells and tissues both in vitro and in vivo (Boletta, Benigni et al. 1997; Goula, Remy et al. 1998; Coll, Chollet et al. 1999; Urban-Klein, Werth et al. 2004; Merkel, Beyerle et al. 2009; Pfeifer, Hasenpusch et al. 2011). However, the clinical application of PEI is limited by its substantial toxicity. Chollet et al. (Chollet, Favrot et al. 2002) injected linear PEI (L-PEI) -pDNA polyplexes into mice intravenously. Signs of toxicity caused by L-PEI were observed 15 minutes after injection of $50 \mathrm{mg}$ of L-PEI/DNA complexes. Increasing the dose up to $100 \mathrm{mg}$ remarkably enhanced the transfection efficiency, but most of the animals suffered from liver necrosis. If the dose was increased to $150 \mathrm{mg}$, all the treated animals died of shock within the first 30 minutes. 
Modified versions of PEI, such as low molecular weight PEI (LMW-PEI) (Kunath, von Harpe et al. 2003) and low branching degree PEI (Fischer, Bieber et al. 1999), have been investigated to reduce the toxicity of the polymers without compromising their $\mathrm{pH}$ buffering capacity (Kunath, von Harpe et al. 2003; Arote, Kim et al. 2007).

On the contrary, polymeric carriers that do not possess $\mathrm{pH}$ buffering properties, such as chitosan and PLL, fail to achieve satisfactory nucleic acid delivery efficiencies because of their inability to induce endosomal escape even though they are capable of binding to nucleic acids and promoting cellular entry (Wagner and Kloeckner 2006). To enhance transfection efficiency, functional moieties were included into these polymeric systems for improving their buffering capacity. Histidine is one of the commonly employed molecules that was added as functional group of polymers or incorporated into peptide sequences to enhance their $\mathrm{pH}$ buffering capacity.

The buffering capacity of histidine is due to the presence of an imidazole ring that has a pKa around 6 and hence can be protonated in a slightly acidic pH (Midoux, Pichon et al. 2009). Midoux et al. (Midoux and Monsigny 1999) reported that partial substitution of PLL with histidine residues resulted in transfection 4-5 orders of magnitude higher than the unmodified PLL/pDNA polyplexes. Upon protonation of the imidazole groups, the histidine residues trigger destabilization of polyplexes and fusion with endosomal membrane, leading to the release of polyplexes into cytosol. Chang et al. (Chang, Higuchi et al. 2010) introduced histidine to the amino groups of chitosan via disulfide bonds. The result showed that histidine-modified chitosan has a broader $\mathrm{pH}$ buffering range, wider distribution in the cytosol as well as a higher transfection level. It is evident that histidine can facilitate pDNA escape from endosomes by increasing the buffering capacity of chitosan inside the acidic compartments. A similar approach was adopted by other researchers to enhance other polycations by introducing imidazole moieties to enhance the $\mathrm{pH}$ buffering capacity and ultimately promote endosomal escape. (Yang, Lee et al. 2006; Moreira, Oliveira et al. 2009).

\subsection{Flip-flop mechanism}

Lipids and liposomes, whether anionic, cationic, neutral and/or $\mathrm{pH}$-sensitive, present another category of non-viral carriers that have been extensively investigated for delivering nucleic acid into mammalian cells. In general, the in vitro and in vivo transfection efficiency of non-cationic lipids or liposomes is relatively low when compared with their cationic counterparts (Legendre and Szoka Jr 1992). Cationic lipids or liposomes form lipoplexes with the anionic nucleic acids through electrostatic interactions and the overall charge of the lipoplexes are usually positive so that they can easily associate with the negatively charged cell surface to promote cellular entry (Felgner, Gadek et al. 1987).

The mechanism of how lipoplexes gain entry into the cells is controversial. According to literature, there are at least two routes of cellular uptake: (i) direct fusion with the plasma membrane; and (ii) endocytosis (Pedroso de Lima, Simões et al. 2001). Physicochemical properties of lipoplexes such as particle size distribution, lipid composition and charge ratio 
may also influence their uptake route. In order to gain a better insight of the uptake mechanism of lipid-based system, Wrobel and Collins studied the interaction between cationic liposomes and model anionic membrane as well as cultured mammalian cells. The results indicated that cell surface binding alone is insufficient for cationic liposomes to gain entry into cells via membrane fusion in the absence of endocytosis (Wrobel and Collins 1995). Zhou et al. investigated the DNA transfection of cationic liposomes containing lipopolylysine and found that only $2 \%$ of the treated cells were transfected and the uptake was mediated by membrane fusion (Zhou and Huang 1994). No correlation between fusion of the lipoplexes with the plasma membrane and the transfection level in monocytic THP-1 cells was observed (Pires, Simões et al. 1999). Nevertheless, some investigators believed that membrane fusion is significant in the internalization of lipoplexes and the contribution of this uptake pathway cannot be completely ruled out.

To find out the intracellular fate of the lipoplexes following endocytosis, an electron microscopic study was carried out by Zabner et al. (Zabner, Fasbender et al. 1995). It was observed that after cellular uptake, lipoplexes were delivered to perinuclear vesicular compartments which fuse with early endosomes. It was also noticed that the dissociation of nucleic acids from lipoplexes and their escape from endosomes are crucial barriers for successful transfection. To elucidate this endosomal escape mechanism of cationic liposomes, Zelphatl et al. identified the biomolecules that are responsible for dissociating of nucleic acids from the lipoplexes and releasing them into cytosol. Anionic liposomes with similar components with the cytoplasmic-facing monolayer of plasma membrane were used as an endosomal model. It was found that the anionic liposomes were able to trigger a rapid release of nucleic acid from lipoplexes. On the basis of this result, a 'flip-flop' mechanism (fig. 2) was proposed by the authors to describe how nucleic acids were able to dissociate from the lipoplexes and escape from the endosomes into the cytosol (Zelphati and Szoka 1996; Zelphati and Szoka 1996). Once inside the endosomes, there is an electrostatic interaction between the cationic lipoplexes and the negatively charged lipids (mainly found in the cytoplasmic-facing leaflet) of the endosomal membrane. The anionic lipids of the endosomal membrane laterally diffuse into the lipoplexes and form charge-neutralized ion pairs with the cationic lipids of the lipoplexes. As a result, the nucleic acids are displaced from the lipoplexes, allowing the nucleic acids to be released into the cytoplasm (Zhou and Huang 1994; Xu and Szoka Jr 1996; Zelphati and Szoka 1996).

Neutral lipids such as the phosphatidylethanolamine (DOPE) are widely used as helper lipids in combination with cationic liposomes. It is well established that inclusion of DOPE in lipoplexes may significantly improve their transfection activity, whereas replacement of DOPE with other neutral phospholipid dioleoylphosphatidylcholine (DOPC) fails to accomplish the helper function. The role of DOPE as helper lipid is attributed to its endosomolytic activity. Zhou and Huang used transmission electron microscopy to study intracellular trafficking of cationic liposomes and found that DOPE-containing lipoplexes can destabilize the endosomal membrane (Zhou and Huang 1994) whereas the DOPC-containing lipoplexes did not show the same effect. A study carried out by Farhood et al. indicated that a substantial amount of DOPE needs to be incorporated into cationic liposomes in order to achieve endosomal membrane 
destabilization (Farhood, Serbina et al. 1995). Both DOPE and DOPC share very similar acyl chain composition (Hui, Langner et al. 1996) and the major difference between the two phospholipids is their headgroups. The former has an ethanolamine head group whereas the latter contains a choline head group. The cone-shape ethanolamine head group of DOPE displays a high tendency to form inverted hexagonal phase especially at acidic $\mathrm{pH}$ while the choline head group of DOPC does not. Zuhorn et al. hypothesized that the formation of hexagonal phase of DOPE containing lipoplexes plays a prominent role both in dissociation of nucleic acids from lipoplexes and in efficient destabilizing endosomal membrane (Zuhorn, Bakowsky et al. 2005).

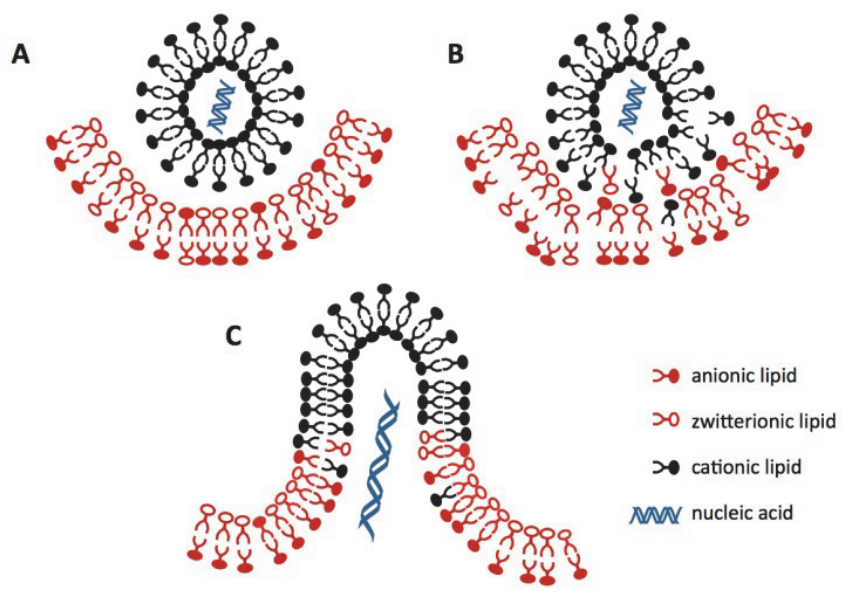

Figure 2. Flip-Flop Mechanism. (A) Lipoplexes are endocytosed and become entrapped inside the early endosomes. (B) There is an electrostatic interaction between the cationic lipoplexes and the anionic lipids which are present in the cytoplasmic-facing side of endosomal membrane. The anionic lipids of the endosomal membrane laterally diffuse into the lipoplexes and form charge-neutralized ion pairs with the cationic lipids of the lipoplexes. (C) The nucleic acids are displaced from the lipoplexes, allowing the nucleic acids entry into the cytoplasm.

Apart from helper lipids, other approaches have been investigated to potentiate endosomal lysis and the release of nucleic acid from lipoplexes to cytosol through the 'flip-flop' mechanism. Simoes et al. (Simoes, Slepushkin et al. 1999) described the use of the pHsensitive endosome-disruptive peptide, GALA, together with lipoplexes (more endosomolytic peptides will be discussed later). A significant improvement in transfection was observed in several cell types and the enhancement was blocked by bafilomycin A1, a specific inhibitor of the vacuolar ATPase proton pump that inhibits the acidification of the endosomes. Since low $\mathrm{pH}$ is a triggering factor of the membrane disruption propensity of GALA, the authors speculated that the membrane destabilizing activity of GALA involves structural changes of the peptide which induce the dissociation of nucleic acids from lipoplexes inside the endosomes. As a result, the dissociated cationic lipids become available to interact with the anionic lipids of the endosomal membrane more readily, leading to the release of nucleic acids into the cytosol via the 'flip-flop' mechanism. 


\subsection{Endosomal membrane fusion or destabilization mechanism}

Cell-penetration peptides (CPPs) have attracted tremendous attention as non-viral nucleic acid delivery vectors in recent years. Typically cationic and/or amphipathic in nature, CPPs are short sequences of amino acids, usually 10-30 residues, claimed to have ability to cross the plasma membrane of living cells. They can facilitate the transportation of various hydrophilic macromolecules including proteins, peptides and nucleic acids into cells without the disruption of plasma membrane (Richard, Melikov et al. 2003). CPPs were originally derived from viruses, with TAT peptide being the first CPP identified and was derived from the transcription activating factor of human immunodeficiency virus 1 (HIV-l) (Brooks, Lebleu et al. 2005). Many different sequences of CPPs were soon discovered and synthetic analogues were also rapidly developed. Until now there are a number of CPPs that were documented for nucleic acid delivery.

CPPs either form complexes with nucleic acids, through electrostatic interaction, or can be incorporated into polymeric and lipidic delivery system. In general, they can be categorized into two main classes (Futaki 2006; Patel, Zaro et al. 2007): (i) Cationic peptides that usually contain arginine and lysine residues, e.g., TAT peptide, penetratin (Derossi, Joliot et al. 1994; Derossi, Calvet et al. 1996; Muratovska and Eccles 2004) and oligoarginines (Futaki 2006); (ii) Amphipathic peptides that consist of both hydrophobic and hydrophilic segments. The amphipathicity of these peptides generates from either the primary structure or the secondary structure. Primary amphipathic peptides are sequentially made up of hydrophobic and hydrophilic residues (Fernández-Carneado, Kogan et al. 2004; Deshayes, Morris et al. 2005), and include e.g., MPG (Simeoni, Morris et al. 2003; Veldhoen, Laufer et al. 2006), pep-1 and its analogues. Secondary amphipathic peptides adopt an amphipathic helical conformation with hydrophilic and hydrophobic regions and include e.g., HA-2 (Wagner, Plank et al. 1992; Plank, Oberhauser et al. 1994), GALA (Li, Nicol et al. 2004), KALA (Wyman, Nicol et al. 1997), and LAH4 derivatives (Kichler, Leborgne et al. 2003; Kichler, Mason et al. 2006; Lam, Liang et al. 2012). The sequences and the endosomal escape mechanism of these peptides are summarized in table 1 . In the past, it was generally accepted that a non-endosomal pathway or direct penetration was the major route of entry for CPPs (Morris, Chaloin et al. 2000). Early studies indicated that the uptake of CPPs into cells could progress at low temperature. It appeared to be energy-independent and insensitive to endocytosis inhibitors (Vivès, Brodin et al. 1997). However recent studies suggested otherwise, that endocytosis may actually be involved in the internalization of CPPs (Richard, Melikov et al. 2003; Lundin, Johansson et al. 2008). Until now, the uptake mechanism still remains controversial (Futaki 2005).

Nevertheless, a variety of CPPs have been shown to enter cells via an endosomal pathway and induce endosomolytic activity. The majority of these membrane-destabilizing peptides were developed to mimic the endosomal disruptive properties of fusogenic sequences of viral fusion proteins. Taking the haemagglutin subunit HA2 of influenza virus as an example, this protein chain is responsible for facilitating membrane fusion. The C-terminal end is embedded in the viral membrane whereas the $\mathrm{N}$-terminal end contains a fusion 
peptide with a sequence of hydrophobic amino acids. Once inside the endosomes, HA undergoes conformation change in response to the low $\mathrm{pH}$ environment and expose the highly conserved hydrophobic N-terminal region. Subsequently, this triggers the fusion of viral membrane with the endosomal membrane, leading to viral genome leakage to cytosol (Stegmann 2000). Wagner et al. introduced HA2 as endosomolytic component in polyplexes containing transferrin/PLL/DNA, resulting in significantly augmentation of the delivery efficiency (Wagner, Plank et al. 1992). In contrast, peptides that are derived from HIV-1 fusion protein gp41 usually adopt a $\mathrm{pH}$-independent membrane fusion capacity and are capable of fusing with both plasma membranes and endosomes at neutral $\mathrm{pH}$ (Fischer, Krausz et al. 2001).

Since the $\alpha$-helical component of the HA2 appears to play a crucial role in endosomal membrane destabilization (Oehlke, Scheller et al. 1998), a series of $\mathrm{pH}$-sensitive amphipathic $\alpha$-helical structural motifs were designed and their structure-activity relationship were investigated. GALA is a synthetic peptide with 30 amino acid residues designed to interact with lipid bilayers at low $\mathrm{pH}$. It contains a histidine and a tryptophan residue, as well as a glutamic acid-alanine-leucine-alanine (EALA) repeat. When the $\mathrm{pH}$ of the surrounding environment drops from 7.0 to 5.0, GALA experiences a conformational change from a random coil to an amphipathic $\alpha$-helix, leading to disruption of model lipid membranes and therefore the release of entrapped aqueous content. The membrane-destabilizing character of this $\mathrm{pH}$ sensitive peptide in an acidic environment raises the possibility of enhancing the delivery of nucleic acid by facilitating endosomal escape (Li, Nicol et al. 2004). Haensler and Szoka Jr et al reported that when GALA is covalently attached to the dendrimer via a disulfide linkage, an increase of gene expression by 2-3 orders of magnitude was observed (Haensler and Szoka Jr 1993). Simoes's study revealed that by incorporating GALA with transferrin containing lipoplexes, there was a significant increase in luciferase gene expression in COS-7 cells (Simoes, Slepushkin et al. 1999). Similarly, introducing GALA peptide into the multifunctional envelope-type nano device (MEND) can lead to improvement of nucleic acid transfer by facilitating nanoparticle endosomal escape (Sasaki, Kogure et al. 2008).

The negatively charged GALA cannot bind with nucleic acid through electrostatic interaction, GALA can only be added as an additional functional component to polyplexes or lipoplexes. Newer peptides were soon developed to combine both nucleic acid binding and membrane destabilizing properties in order to produce a simpler delivery system. KALA is a modified version of GALA by partially replacing glutamic acid with lysine. It is one of the first generation peptides that is designed to bind nucleic acids as well as destabilize the endosomal membranes. Interestingly, the membrane destabilization mechanism of KALA is substantially different from that of GALA although they share similar amino acid sequence. KALA adopts $\alpha$-helix conformation in a wide $\mathrm{pH}$ range and undergoes a $\mathrm{pH}$-dependent conformational change from amphipathic $\alpha$-helical to a mixture of $\alpha$-helix and random coil as the $\mathrm{pH}$ is lowered (Wyman, Nicol et al. 1997). Apart from GALA and KALA, other amphipathic peptides that attain endosomal escape ability that is related to their $\alpha$-helical structure include the Hel series peptides (Niidome, Takaji et al. 


\begin{tabular}{|c|c|c|c|}
\hline Peptide & Primary Sequence & $\begin{array}{l}\text { Endosomal Escape } \\
\text { Mechanism } \\
\end{array}$ & Reference \\
\hline TAT & GRKKRRQRRRPPQ & $\begin{array}{l}\text { Unclear, endosomal } \\
\text { escape is inefficient }\end{array}$ & $\begin{array}{l}\text { (Vives 2003; Brooks, } \\
\text { Lebleu et al. 2005; } \\
\text { Lee, Johnson } \\
\text { et al. 2011) }\end{array}$ \\
\hline Penetratin & RQIKIWFQNRRMKWKK & $\begin{array}{l}\text { Unclear, endosomal } \\
\text { escape is inefficient }\end{array}$ & $\begin{array}{l}\text { (Muratovska } \\
\text { and Eccles 2004) }\end{array}$ \\
\hline EBI & $\begin{array}{l}\text { LIRLWSHLIHIWFQNRRLKW } \\
\text { KKK }\end{array}$ & $\begin{array}{l}\text { Membrane } \\
\text { destabilization }\end{array}$ & $\begin{array}{l}\text { (Lundberg, } \\
\text { El-Andaloussi } \\
\text { et al. 2007) }\end{array}$ \\
\hline MPG & $\begin{array}{l}\text { GALFLGFLGAAGSTMGAWS } \\
\text { QPKKKRKV }\end{array}$ & $\begin{array}{l}\text { Bypass endosomes } \\
\text { through non-endosomal } \\
\text { uptake }\end{array}$ & $\begin{array}{l}\text { (Morris, Vidal } \\
\text { et al. 1997; } \\
\text { Simeoni, Morris } \\
\text { et al. 2003) }\end{array}$ \\
\hline HGP & $\begin{array}{l}\text { LLGRRGWEVLKYWWNLLQ } \\
\text { YWSQELC }\end{array}$ & $\begin{array}{l}\text { Membrane } \\
\text { destabilization, possibly } \\
\text { pore formation }\end{array}$ & $\begin{array}{l}\text { (Kwon, Bergen } \\
\text { et al. 2008) }\end{array}$ \\
\hline Pep-2 & $\begin{array}{l}\text { KETWFETWFTEWSQPKKKR } \\
\text { KV }\end{array}$ & $\begin{array}{l}\text { Bypass endosomes } \\
\text { through non-endosomal } \\
\text { uptake }\end{array}$ & $\begin{array}{l}\text { (Morris, Depollier } \\
\text { et al. 2001; Gros, } \\
\text { Deshayes et al. 2006; } \\
\text { Deshayes, } \\
\text { Morris et al. 2008) }\end{array}$ \\
\hline $\begin{array}{l}\text { HA-2 } \\
\text { derived } \\
\text { fusogenic } \\
\text { peptide }\end{array}$ & $\begin{array}{l}\text { GLFGAIAGFIEGGWTGMIDG } \\
\text { WYG }\end{array}$ & $\begin{array}{l}\text { Membrane fusion and } \\
\text { destabilization }\end{array}$ & $\begin{array}{l}\text { (Wagner, Plank } \\
\text { et al. 1992; } \\
\text { Plank, Oberhauser } \\
\text { et al. 1994; } \\
\text { Navarro-Quiroga, } \\
\text { Antonio González- } \\
\text { Barrios et al. 2002) }\end{array}$ \\
\hline H5WYG & $\begin{array}{l}\text { GLFHAIAHFIHGGWHGLIHG } \\
\text { WYG }\end{array}$ & $\begin{array}{l}\text { Membrane } \\
\text { destabilization }\end{array}$ & $\begin{array}{l}\text { (Midoux, Kichler } \\
\text { et al. 1998; } \\
\text { Pichon, Gonçalves } \\
\text { et al. 2001) }\end{array}$ \\
\hline INF-7 & $\begin{array}{l}\text { GLFEAIEGFIENGWEG } \\
\text { MIDGWYG }\end{array}$ & $\begin{array}{l}\text { Membrane fusion and } \\
\text { destabilization }\end{array}$ & $\begin{array}{l}\text { (Plank, Oberhauser } \\
\text { et al. 1994; } \\
\text { van Rossenberg, } \\
\text { Sliedregt-Bol } \\
\text { et al. 2002; } \\
\text { Funhoff, van } \\
\text { Nostrum et al. 2005) }\end{array}$ \\
\hline
\end{tabular}




\begin{tabular}{|c|c|c|c|}
\hline Peptide & Primary Sequence & $\begin{array}{l}\text { Endosomal Escape } \\
\text { Mechanism }\end{array}$ & Reference \\
\hline $\begin{array}{l}\text { E5 \& } \\
\text { E5CA }\end{array}$ & $\begin{array}{l}\text { GLFGAIAGFIEGGWTGMIDG } \\
\text { GLFEAIAEFIEGGWEGLIEGC } \\
\text { A }\end{array}$ & $\begin{array}{l}\text { Membrane fusion and } \\
\text { destabilization }\end{array}$ & $\begin{array}{l}\text { (Midoux, Mendes } \\
\text { et al. 1993; } \\
\text { Pichon, Freulon } \\
\text { et al. 1997; } \\
\text { Vliegenthart, } \\
\text { Knollen et al. 1999; } \\
\text { Klink, Chao } \\
\text { et al. 2001) }\end{array}$ \\
\hline JTS-1 & GLFEALLELLESLWELLLEA & $\begin{array}{l}\text { Membrane } \\
\text { destabilization }\end{array}$ & $\begin{array}{l}\text { (Gottschalk, Sparrow } \\
\text { et al. 1996; Fominaya, } \\
\text { Gasset et al. 2000; } \\
\text { van Rossenberg, } \\
\text { Sliedregt-Bol } \\
\text { et al. 2002; Vlasov, } \\
\text { Lesina et al. 2005) }\end{array}$ \\
\hline ppTG1 & GLFKALLKLLKSLWKLLLKA & $\begin{array}{l}\text { Membrane } \\
\text { destabilization }\end{array}$ & $\begin{array}{l}\text { (Rittner, Benavente } \\
\text { et al. 2002; Numata } \\
\text { and Kaplan 2010) }\end{array}$ \\
\hline GALA & $\begin{array}{l}\text { WEAALAEALAEALAEHLAE } \\
\text { ALAEALEALAA }\end{array}$ & $\begin{array}{l}\text { Membrane } \\
\text { destabilization, Pore } \\
\text { formation \& flip-flop of } \\
\text { membrane lipids }\end{array}$ & $\begin{array}{l}\text { (Parente, Nir } \text { et al. } \\
\text { 1990; Haensler and } \\
\text { Szoka Jr 1993; Fattal, } \\
\text { Nir et al. 1994; Plank, } \\
\text { Oberhauser } \\
\text { et al. 1994; Simoes, } \\
\text { Slepushkin } \\
\text { et al. 1999; } \\
\text { Li, Nicol et al. 2004) } \\
\end{array}$ \\
\hline KALA & $\begin{array}{l}\text { WEAKLAKALAKALAKHLA } \\
\text { KALAKALKACEA }\end{array}$ & $\begin{array}{l}\text { Membrane } \\
\text { destabilization }\end{array}$ & $\begin{array}{l}\text { (Wyman, } \\
\text { Nicol et al. 1997; } \\
\text { Li, Nicol et al. 2004; } \\
\text { Min, Lee et al. 2006) }\end{array}$ \\
\hline CADY & $\begin{array}{l}\text { GLWRALWRLLRSLWRLLWR } \\
\text { A }\end{array}$ & $\begin{array}{l}\text { Bypass endosomes } \\
\text { through non-endosomal } \\
\text { uptake }\end{array}$ & $\begin{array}{l}\text { (Crombez, Aldrian- } \\
\text { Herrada et al. 2008) }\end{array}$ \\
\hline $\begin{array}{l}\text { Peptide } 46 \\
\& \\
\text { analogues }\end{array}$ & $\begin{array}{l}\text { LARLLARLLARLLRALLRAL } \\
\text { LRAL }\end{array}$ & $\begin{array}{l}\text { Membrane } \\
\text { destabilization }\end{array}$ & $\begin{array}{l}\text { (Niidome, Ohmori } \\
\text { et al. 1997) }\end{array}$ \\
\hline \begin{tabular}{l|} 
HEL \\
peptides \& \\
analogues
\end{tabular} & KLLKLLLKLWKKLLKLLK & $\begin{array}{l}\text { Membrane } \\
\text { destabilization }\end{array}$ & $\begin{array}{l}\text { (Ohmori, Niidome } \\
\text { et al. 1998; Niidome, } \\
\text { Takaji et al. 1999) }\end{array}$ \\
\hline
\end{tabular}




\begin{tabular}{|l|l|l|l|}
\hline Peptide & Primary Sequence & $\begin{array}{l}\text { Endosomal Escape } \\
\text { Mechanism }\end{array}$ & Reference \\
\hline $\begin{array}{l}\text { LAH4 \& } \\
\text { analogues }\end{array}$ & $\begin{array}{l}\text { KKALLALALHHLAHLALHL } \\
\text { ALALKKA }\end{array}$ & $\begin{array}{l}\text { Membrane } \\
\text { destabilization }\end{array}$ & $\begin{array}{l}\text { Kichler, Leborgne } \\
\text { et al. 2003; Kichler, } \\
\text { Mason } \text { et al. 2006; } \\
\text { Lam, Liang } \\
\text { et al. 2012) }\end{array}$ \\
\hline
\end{tabular}

Table 1. The sequences and the endosomal escape mechanism of selected CPPs that are being investigated for nucleic acid delivery.

1999), INF 7 (Plank, Oberhauser et al. 1994), HGP (Kwon, Bergen et al. 2008), JTS-1 (Gottschalk, Sparrow et al. 1996), EBI (Lundberg, El-Andaloussi et al. 2007), ppTG1 (Rittner, Benavente et al. 2002) and CADY (Crombez, Aldrian-Herrada et al. 2008; Konate, Crombez et al. 2010).

The LAH4 peptide and its derivatives are another class of peptide that exhibits efficient gene transfer activity (Kichler, Leborgne et al. 2003; Lam, Liang et al. 2012). Peptides of the LAH4 family are synthetic cationic amphipathic peptides containing a variable number of histidine residues and hydrophobic amino acids (mainly alanines and leucines). They were initially designed to investigate the interactions that determine the alignment of membraneassociated proteins (Bechinger 1996; Vogt and Bechinger 1999). In vitro transfection experiments indicated that peptides with four to five histidine residues in the central region of the sequence achieved high transfection efficiency that is comparable to PEI. The transfection activity was significantly abolished in the presence of proton pump inhibitor bafilomycin A1, suggesting acidification is important for these peptides to mediate high transfection level. In a model membrane experiment, it was noticed that there was a preferential peptide-lipid interaction between LAH4 derivatives and anionic lipids, leading to the disruption of the lipid acyl chains in the acidic environment (Mason, Martinez et al. 2006). Furthermore, LAH4 peptides experience a $\mathrm{pH}$-dependent conformational change from transmembrane orientation at neutral $\mathrm{pH}$ to an in-plane orientation at low $\mathrm{pH}$. The $\mathrm{pH}$ at which the conformation transition takes place is crucial and highly affects the transfection efficiency (Bechinger 1996; Vogt and Bechinger 1999; Kichler, Leborgne et al. 2003). Based on these observations, it was proposed that at neutral $\mathrm{pH}$, LAH4 adopts a transmembrane orientation without disrupting the membrane integrity. During acidification of the endosomes, the imidazole groups of histidine residues become protonated and the peptide changes to an in-plane alignment and interact with the anionic lipids in the endosomal membrane. Membrane destabilization occurs, followed by the release of nucleic acid into the cytosol (Kichler, Mason et al. 2006).

\subsection{Pore formation}

Pore formation is another mechanism to explain the endosomal escape of peptide-based nucleic acid delivery systems. Parente et al. (Parente, Nir et al. 1990) investigated contentleaking kinetics of peptide GALA from phospholipid vesicles over a wide range of $\mathrm{pH}$. As 
previously mentioned, GALA undergoes a $\mathrm{pH}$-dependent conformational change to give a helical structure at acidic environment. It was suggested that leakage from phospholipid vesicles is promptly initiated by low $\mathrm{pH}(\mathrm{pH}<6)$ and is rapidly terminated when the $\mathrm{pH}$ is raised to 7.5. The author assumes that GALA becomes incorporated into the vesicle bilayer and aggregates to form a pore with diameter ranges from 5 to $10 \AA$. Fattal et al. further investigated the mechanism of pore-forming peptides GALA in details. They concluded that pore formation is a key event that may result in phospholipid flip-flop of biological membranes, leading to the releasing of contents (Fattal, Nir et al. 1994). Simoes et al. (Simoes, Slepushkin et al. 1999) combined GALA with lipoplexes and found significant improvement of transfection in several cell cells. The results indicated that the cellular uptake of lipoplexes is though endocytosis and the endosomal escape play a crucial role in intracellular delivery of lipoplexes. However, the authors believe that the dimension of the pores (5 to $10 \AA$ ) formed by this peptide may not be big enough to permit the escape of nucleic acid from endosomes. Multiple mechanisms may be accounted for the enhancement of transfection efficiency, including structural changes of the peptide, facilitation of nucleic acid dissociation from the lipoplexes and the flip-flop mechanism.

\subsection{Photochemical internalization (PCI)}

Photochemical internalization (PCI) is a light-directed delivery technology that utilizes photosensitizers to facilitate the transport of membrane impermeable macromolecules from endocytic vesicles into cytoplasm. The mechanism of PCI as an endosomal escape enhancer strategy is very straight-forward (Fig.3). Photosensitizers that are employed in the PCI technology are usually amphiphilic compounds which can bind to and localize in the plasma membrane. After being taken up by the cells through endocytosis, the photosensitizers are confined to the endosomal membranes and remain inactive until triggered by light with specific wavelengths matching their absorption spectra (Selbo, Weyergang et al. 2010). Once activated, they induce the formation of highly reactive oxygen species, mainly singlet oxygen, leading to the rupture of endosomes and lysosomes membrane. As a result, macromolecules that are trapped inside the endosomes/lysosomes can be liberated into the cytosol (Berg, Kristian Selbo et al. 1999). Photosensitizers used in clinical application are highly reactive reagents with short range of action $(10-20 \mathrm{~nm})$ and short life-time (0.01-0.04 $\mu \mathrm{s})$, thus restricting the damaging effect to the production site (within the endosomal membrane) without affecting other cellular components (Moan and Berg 1991; Berg, Weyergang et al. 2010). Most of the photosensitizers do not localize to the nucleus of the cells, thereby reducing the possibility of causing any mutagenic effects (Dougherty, Henderson et al. 1998).

PCI was initially investigated for anti-tumour drug delivery. A synergistic effect of combining PCI with chemotherapeutic agents was found. PCI principally targets cellular endocytosis that may affect the distribution of molecules that are taken up by the cells via endosomal pathway. It was later employed as a tool to improve the cellular delivery of a large variety of bioactive macromolecules and nucleic acids including pDNA, siRNA and 
oligonucleotides (Selbo, Weyergang et al. 2010). Examples of photosensitizers that are used in non-viral nucleic acid delivery including disulfonated meso-tetraphenylporphine (TPPS 2 a) (Prasmickaite, Høgset et al. 2000; Kloeckner, Prasmickaite et al. 2004; Maurice-Duelli, Ndoye et al. 2004; Ndoye, Merlin et al. 2004; Ndoye, Dolivet et al. 2006; Oliveira, Fretz et al. 2007; Boe, Longva et al. 2008; Raemdonck, Naeye et al. 2009; Bøe, Sæbøe-Larssen et al. 2010), disulfonated aluminium phthalocyanine (AlPcS2a) (Berg, Prasmickaite et al. 2003; Hellum, Høgset et al. 2003; Ndoye, Dolivet et al. 2006; Yip, Weyergang et al. 2007), Zincphthalocyanine (Zn-Pc) dendrimer (Nishiyama, Iriyama et al. 2005; Arnida, Nishiyama et al. 2006) and 5,10,15-tri(4-acetamidophenyl)-20-mono(4-carboxyl-phenyl)porphyrin (TAMCPP) conjugated to G4 PAMAM dendrimer (Shieh, Peng et al. 2008).

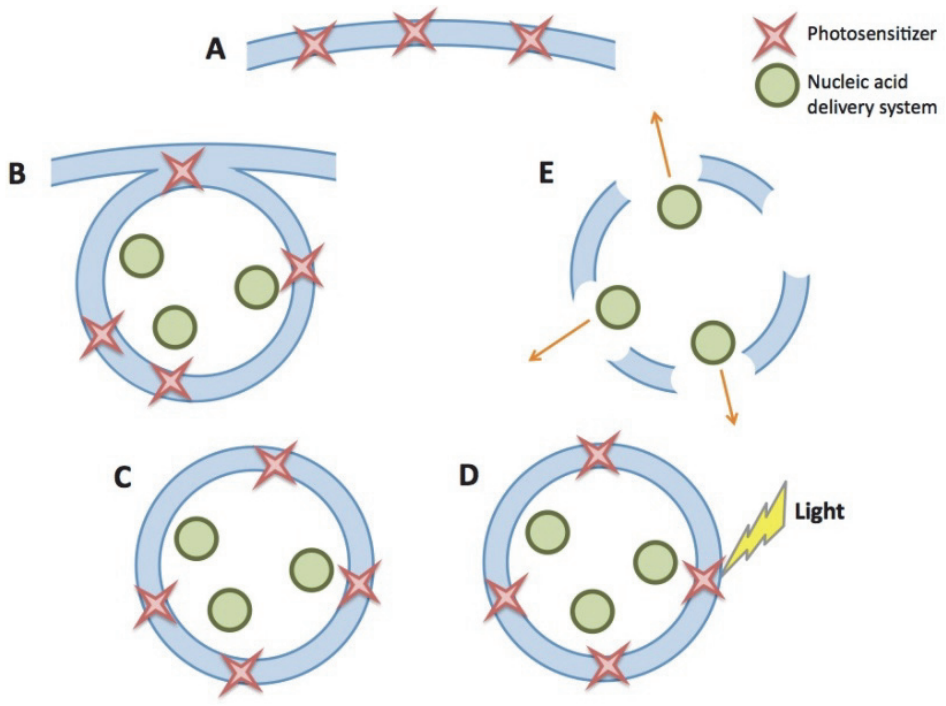

Figure 3. The mechanism of photochemical internalization technology. (A) Photosensitizers bind to and localize in the plasma membrane. (B) Photosensitizers can be taken up by the cells through endocytosis with the delivery systems. (C) Photosensitizers are confined to the endosomal membrane and remain inactive. (D) Photosensitizers are activated by illumination and induce the formation of highly reactive oxygen species, leading to the rupture of endosomes /lysosomes membrane. (E) Molecules that are trapped inside the endosomes/lysosomes can be liberated into the cytosol.

To employ PCI in clinical applications, the penetration of light into the deep tissue is an important issue (Oliveira, Fretz et al. 2007). With the development of fiber optics and laser technology, the control of illumination to sites that are deep inside the human body becomes possible, e.g. gastrointestinal tract, urogenital organs, lungs, brain and pancreas (Dougherty, Henderson et al. 1998; Chatterjee, Fong et al. 2008). PCI mediated therapy can be used in many regions of the body where light delivery can be achieved and where local activation of a drug is desirable. A photosensizer is injected as a single dose prior to light activation. Parameters such as the dose of photosentizers and light, as well as the time interval between administration of photosentiziers and drugs must be carefully optimized. In vivo 
experiments demonstrated that $\mathrm{PCI}$, in combination with a chemotherapeutic agent, has a good effect on cancer treatment (Selbo, Sivam et al. 2001; Berg, Dietze et al. 2005; Hirschberg, Zhang et al. 2009; Norum, Gaustad et al. 2009). In the field of nucleic acid delivery, it has been shown that PCI was able to transfer pDNA and siRNA into cytosol efficiently to enhance their biological effects in vitro. Only a number of in vivo studies have been carried out to demonstrate the feasibility of PCI technology to enhance the delivery of pDNA to conjunctival tissue (Nishiyama, Iriyama et al. 2005) and tumour tissues (Ndoye, Dolivet et al. 2006), as well as the delivery of siRNA to a tumour site (Oliveira, Hogset et al. 2008). The result was very promising. Perhaps more effort should be invested to further develop this technology for clinical use.

\subsection{Other endosomal escape mechanisms}

Exogenous additives, such as chloroquine and inactivated adenovirus, have been exploited to promote endosomal escape and enhance the efficiency of nucleic acid delivery. Chloroquine is a weak base that can rapidly penetrate the plasma membrane, accumulate in acidic vesicles and increase the $\mathrm{pH}$ of the acidic compartment (Maxfield 1982; Mellman, Fuchs et al. 1986). Preventing endosome acidification may subsequently inhibit hydrolytic enzymes such as proteases and nucleases (Cotten, Längle-Rouault et al. 1990). Chloroquine also causes the swelling and rupture of endosomal vesicle by increasing the osmotic pressure inside the acidic compartment (Khalil, Kogure et al. 2006). Since it can neutralize acidic compartment and induce rupture of endocytic vesicles, adding chloroquine is an alternative measure to improve nucleic acid transfer (Erbacher, Roche et al. 1996).

A number of early studies found that chloroquine is able to enhance DNA transfection in various cell types (Luthman and Magnusson 1983; Cotten, Längle-Rouault et al. 1990; Erbacher, Roche et al. 1996). Chloroquine promotes escape of polyplexes or lipoplexes from endosome via increasing endosomal $\mathrm{pH}$ and hindering endosome fusion with lysosome. To date, chloroquine has been widely used to elucidate the uptake mechanism of non-viral nucleic acid delivery systems (Legendre and Szoka Jr 1992; Simeoni, Morris et al. 2003; Lehto, Abes et al. 2010). However, it is worth noting that chloroquine does not always lead to an improvement of transfection efficiency, depending on the uptake pathway of the delivery systems. Haensler and Szoka reported that transfection of PAMAM was not affected by the presence of chloroquine (Haensler and Szoka Jr 1993). The authors suggested the endosomal lysis activity of PAMAM is strong enough to allow liberation of its content to cytosol with and without the presence of chloroquine. Legendre and Szoka (Legendre and Szoka Jr 1992) described an increase in transfection efficiency after chloroquine was added to DOTMA/DOPE liposomes. Interestingly, chloroquine exerts a negative effect on carcinoma cells transfected by DOPE/CHEMS $\mathrm{pH}$-sensitive liposomes. The authors explained that the membrane destabilization activity of $\mathrm{pH}$-sensitive liposome is attenuated when the acidic environment of endosome is perturbed by chloroquine. Transfection is a complicated process involving multiple steps, such as cellular binding, internalization and nuclear transport (in the case of DNA delivery). Apart from endosomal escape, other factors may also affect the eventual transfection efficiency. 
Besides chloroquine, physically coupling chemically inactivated adenovirus particles is another approach for promoting endosomal escape. This method takes the advantage of the endosomolytic activity of adenovirus to facilitate the release of nucleic acids from the endosomes (Curiel, Agarwal et al. 1991; Cotten, Wagner et al. 1992; Wagner, Zatloukal et al. 1992). Curiel et al. explored the application of adenovirus as an endosome disruption agent. The inactivated adenoviruses were coupled with transferring-polyplexes. It was observed that pDNA delivery into HeLa cells was improved 1000-fold or more when replicationdefective adenovirus particles were present (Curiel, Agarwal et al. 1991).

However, the application of both chloroquine and inactivated adenovirus particles are limited due to safety concern. Although chloroquine is approved by the FDA as an antimalaria medication, it is found to be toxic to many cell types and can trigger gastrointestinal and nervous adverse effects in high dose (Pack, Putnam et al. 2000). For defective adenovirus particles, the complexity of vector production and potential immunogenicity raised by the virus components make this strategy problematic (Pack, Hoffman et al. 2005). Unless the safety issues can be solved, both methods will remain unsuitable for clinical use.

\section{Conclusion}

Non-viral vectors are considered to be promising vehicles for delivering therapeutic nucleic acids because of their relatively safe profile and high versatility as compared to their viral counterparts. However, the transfection efficiency of non-viral vectors is less than satisfactory for clinical purpose. The endocytosis pathway is a major route for the cellular entry of non-viral nucleic acid delivery agents. Poor endosomal escape of non-viral systems pose a major challenge for the intracellular delivery of nucleic acids. An ideal nucleic acid delivery system should fulfill several criteria: negligible toxicity, biocompatible and biodegradable, offer protection to nucleic acids from enzymatic degradation, facilitate cellular uptake, promote endosomal escape and release the nucleic acids at site of action. Elucidation of the mechanism of endosomal escape is beneficial in the development of more effective non-viral delivery vectors. However, the uptake and cytoplasmic transportation mechanisms of a variety of non-viral nucleic acid carriers still need to be investigated in more detail. In the future, with the development of cell imaging techniques such as high resolution, spinning disk live cell confocal imaging and the fluorescence correlation spectroscope, the details of intracellular trafficking of non-viral nucleic acid delivery systems will be unveiled. This will guide the future design and development of novel efficient non-viral nucleic acid delivery vectors.

\section{Author details}

Wanling Liang and Jenny K.W. Lam

Department of Pharmacology \& Pharmacy, Li Ka Shing Faculty of Medicine,

The University of Hong Kong, Hong Kong SAR 


\section{Acknowledgement}

The authors would like to thank Seed Funding Programme for Basic Research (2009091159006, 201011159060), The University of Hong Kong for financial support. The authors are grateful to Dr A James Mason for critical reading of the manuscript.

\section{References}

Aiuti, A., F. Cattaneo, et al. (2009). "Gene therapy for immunodeficiency due to adenosine deaminase deficiency." New England Journal of Medicine 360(5): 447-458.

Arnida, A., N. Nishiyama, et al. (2006). "Novel ternary polyplex of triblock copolymer, pDNA and anionic dendrimer phthalocyanine for photochemical enhancement of transgene expression." Journal of Controlled Release 116(2): e75.

Arote, R., T. H. Kim, et al. (2007). "A biodegradable poly (ester amine) based on polycaprolactone and polyethylenimine as a gene carrier." Biomaterials 28(4): 735-744.

Bøe, S., S. Sæbøe-Larssen, et al. (2010). "Light-Induced Gene Expression Using Messenger RNA Molecules." Oligonucleotides 20(1): 1-6.

Bally, M. B., P. Harvie, et al. (1999). "Biological barriers to cellular delivery of lipid-based DNA carriers." Advanced Drug Delivery Reviews 38(3): 291-315.

Baum, C., J. Düllmann, et al. (2003). "Side effects of retroviral gene transfer into hematopoietic stem cells." Blood 101(6): 2099-2113.

Bechinger, B. (1996). "Towards membrane protein design: $\mathrm{pH}$-sensitive topology of histidine-containing polypeptides." Journal of Molecular Biology 263(5): 768-775.

Behr, J. P. (1997). "The proton sponge: a trick to enter cells the viruses did not exploit." Chimia International Journal for Chemistry 51(1,2): 34-36.

Berg, K., A. Dietze, et al. (2005). "Site-specific drug delivery by photochemical internalization enhances the antitumor effect of bleomycin." Clinical Cancer Research 11(23): 8476-8485.

Berg, K., P. Kristian Selbo, et al. (1999). "Photochemical Internalization." Cancer Research 59(6): 1180-1183.

Berg, K., A. Weyergang, et al. (2010) "The Potential of Photochemical Internalization (PCI) for the Cytosolic Delivery of Nanomedicines" in Organelle-Specific Pharmaceutical Nanotechnology: John Wiley \& Sons, Inc. p. 311-322.

Bernstein, E., A. A. Caudy, et al. (2001). "Role for a bidentate ribonuclease in the initiation step of RNA interference." Nature 409(6818): 363-365.

Boe, S., A. S. Longva, et al. (2008). "Evaluation of various polyethylenimine formulations for light-controlled gene silencing using small interfering RNA molecules." Oligonucleotides 18(2): 123-132.

Boletta, A., A. Benigni, et al. (1997). "Nonviral gene delivery to the rat kidney with polyethylenimine." Human Gene Therapy 8(10): 1243-1251.

Boussif, O., F. Lezoualc'h, et al. (1995). "A versatile vector for gene and oligonucleotide transfer into cells in culture and in vivo: polyethylenimine." Proceedings of the National Academy of Sciences 92(16): 7297. 
Brooks, H., B. Lebleu, et al. (2005). "Tat peptide-mediated cellular delivery: back to basics." Advanced Drug Delivery Reviews 57(4): 559-577.

Chang, K. L., Y. Higuchi, et al. (2010). "Efficient gene transfection by histidine-modified chitosan through enhancement of endosomal escape." Bioconjugate Chemistry 21(6): 10871095.

Chatterjee, D. K., L. S. Fong, et al. (2008). "Nanoparticles in photodynamic therapy: An emerging paradigm." Advanced drug delivery reviews 60(15): 1627-1637.

Cho, Y. W., J. D. Kim, et al. (2003). "Polycation gene delivery systems: escape from endosomes to cytosol." Journal of Pharmacy and Pharmacology 55(6): 721-734.

Chollet, P., M. C. Favrot, et al. (2002). "Side-effects of a systemic injection of linear polyethylenimine-DNA complexes." The Journal of Gene Medicine 4(1): 84-91.

Coll, J. L., P. Chollet, et al. (1999). "In vivo delivery to tumors of DNA complexed with linear polyethylenimine." Human Gene Therapy 10(10): 1659-1666.

Cotten, M., F. Längle-Rouault, et al. (1990). "Transferrin-polycation-mediated introduction of DNA into human leukemic cells: stimulation by agents that affect the survival of transfected DNA or modulate transferrin receptor levels." Proceedings of the National Academy of Sciences 87(11): 4033.

Cotten, M., E. Wagner, et al. (1992). "High-efficiency receptor-mediated delivery of small and large (48 kilobase gene constructs using the endosome-disruption activity of defective or chemically inactivated adenovirus particles." Proceedings of the National Academy of Sciences 89(13): 6094.

Crombez, L., G. Aldrian-Herrada, et al. (2008). "A new potent secondary amphipathic cellpenetrating peptide for siRNA delivery into mammalian cells." Molecular Therapy 17(1): 95-103.

Cull, V. S., E. J. Bartlett, et al. (2002). "Type I interferon gene therapy protects against cytomegalovirus-induced myocarditis." Immunology 106(3): 428-437.

Curiel, D. T., S. Agarwal, et al. (1991). "Adenovirus enhancement of transferrin-polylysinemediated gene delivery." Proceedings of the National Academy of Sciences 88(19): 8850.

Davis, M. E., J. E. Zuckerman, et al. (2010). "Evidence of RNAi in humans from systemically administered siRNA via targeted nanoparticles." Nature 464(7291): 1067-1070.

Derossi, D., S. Calvet, et al. (1996). "Cell internalization of the third helix of the Antennapedia homeodomain is receptor-independent." Journal of Biological Chemistry 271(30): 18188-18193.

Derossi, D., A. H. Joliot, et al. (1994). "The third helix of the Antennapedia homeodomain translocates through biological membranes." Journal of Biological Chemistry 269(14): 10444-10450.

Deshayes, S., M. Morris, et al. (2005). "Cell-penetrating peptides: tools for intracellular delivery of therapeutics." Cellular and Molecular Life Sciences 62(16): 1839-1849.

Deshayes, S., M. Morris, et al. (2008). "Delivery of proteins and nucleic acids using a noncovalent peptide-based strategy." Advanced Drug Delivery Reviews 60(4-5): 537-547.

DeVincenzo, J., J. E. Cehelsky, et al. (2008). "Evaluation of the safety, tolerability and pharmacokinetics of ALN-RSV01, a novel RNAi antiviral therapeutic directed against respiratory syncytial virus (RSV)." Antiviral Research 77(3): 225-231. 
DeVincenzo, J., R. Lambkin-Williams, et al. (2010). "A randomized, double-blind, placebocontrolled study of an RNAi-based therapy directed against respiratory syncytial virus." Proceedings of the National Academy of Sciences 107(19): 8800.

Dougherty, T. J., B. W. Henderson, et al. (1998). "Photodynamic therapy." Journal of the National Cancer Institute 90(12): 889-905.

Edelstein, M. L., M. R. Abedi, et al. (2007). "Gene therapy clinical trials worldwide to 2007-an update." The Journal of Gene Medicine 9(10): 833-842.

El-Aneed, A. (2004). "An overview of current delivery systems in cancer gene therapy." Journal of Controlled Release 94(1): 1-14.

El Ouahabi, A., M. Thiry, et al. (1997). "The role of endosome destabilizing activity in the gene transfer process mediated by cationic lipids." FEBS letters 414(2): 187-192.

Elbashir, S. M., W. Lendeckel, et al. (2001). "RNA interference is mediated by 21-and 22nucleotide RNAs." Genes \& Development 15(2): 188-200.

Endoh, T. and T. Ohtsuki (2009). "Cellular siRNA delivery using cell-penetrating peptides modified for endosomal escape." Advanced Drug Delivery Reviews 61(9): 704-709.

Erbacher, P., A. C. Roche, et al. (1996). "Putative role of chloroquine in gene transfer into a human hepatoma cell line by DNA/lactosylated polylysine complexes." Experimental Cell Research 225(1): 186-194.

Ewert, K., A. Zidovska, et al. (2010). "Cationic Liposome-Nucleic Acid Complexes for Gene Delivery and Silencing: Pathways and Mechanisms for Plasmid DNA and siRNA." Nucleic Acid Transfection: 191-226.

Farhood, H., N. Serbina et al. (1995). "The role of dioleoyl phosphatidylethanolamine in cationic liposome mediated gene transfer." Biochimica et Biophysica Acta (BBA) Biomembranes 1235: (2) 289-295 Journal name - italics (Biochimica et Biophysica Acta (BBA) - Biomembranes)

Fattal, E., S. Nir, et al. (1994). "Pore-forming peptides induce rapid phospholipid flip-flop in membranes." Biochemistry 33(21): 6721-6731.

Felgner, P. L., T. R. Gadek, et al. (1987). "Lipofection: a highly efficient, lipid-mediated DNAtransfection procedure." Proceedings of the National Academy of Sciences 84(21): 7413.

Fernández-Carneado, J., M. J. Kogan, et al. (2004). "Amphipathic peptides and drug delivery." Peptide Science 76(2): 196-203.

Fire, A., S. Q. Xu, et al. (1998). "Potent and specific genetic interference by double-stranded RNA in Caenorhabditis elegans." Nature 391(6669): 806-811.

Fischer, D., T. Bieber, et al. (1999). "A novel non-viral vector for DNA delivery based on low molecular weight, branched polyethylenimine: effect of molecular weight on transfection efficiency and cytotoxicity." Pharmaceutical research 16(8): 1273-1279.

Fischer, P. M., E. Krausz, et al. (2001). "Cellular delivery of impermeable effector molecules in the form of conjugates with peptides capable of mediating membrane translocation." Bioconjugate chemistry 12(6): 825-841.

Fominaya, J., M. Gasset, et al. (2000). "An optimized amphiphilic cationic peptide as an efficient non-viral gene delivery vector." The Journal of Gene Medicine 2(6): 455-464. 
Funhoff, A. M., C. F. van Nostrum, et al. (2005). "Cationic polymethacrylates with covalently linked membrane destabilizing peptides as gene delivery vectors." Journal of Controlled Release 101(1): 233-246.

Futaki, S. (2005). "Membrane-permeable arginine-rich peptides and the translocation mechanisms." Advanced Drug Delivery Reviews 57(4): 547-558.

Futaki, S. (2006). "Oligoarginine vectors for intracellular delivery: Design and cellular-uptake mechanisms." Peptide Science 84(3): 241-249.

Gaspar, H. B., K. L. Parsley, et al. (2004). "Gene therapy of X-linked severe combined immunodeficiency by use of a pseudotyped gammaretroviral vector." The Lancet 364(9452): 2181-2187.

Godbey, W., K. K. Wu, et al. (1999). "Poly (ethylenimine) and its role in gene delivery." Journal of Controlled Release 60(2-3): 149-160.

Gottschalk, S., J. Sparrow, et al. (1996). "A novel DNA-peptide complex for efficient gene transfer and expression in mammalian cells." Gene therapy 3(5): 448.

Goula, D., J. Remy, et al. (1998). "Size, diffusibility and transfection performance of linear PEI/DNA complexes in the mouse central nervous system." Gene Therapy 5(5): 712.

Griesenbach, U. and E. W. F. W. Alton (2009). "Cystic fibrosis gene therapy: successes, failures and hopes for the future." Expert Review of Respiratory Medicine 3(4): 363-371.

Gros, E., S. Deshayes, et al. (2006). "A non-covalent peptide-based strategy for protein and peptide nucleic acid transduction." Biochimica et Biophysica Acta (BBA)-Biomembranes 1758(3): 384-393.

Hacein-Bey-Abina, S., A. Garrigue, et al. (2008). "Insertional oncogenesis in 4 patients after retrovirus-mediated gene therapy of SCID-X1." The Journal of Clinical Investigation 118(9): 3132.

Hacein-Bey-Abina, S., C. von Kalle, et al. (2003). "A serious adverse event after successful gene therapy for X-linked severe combined immunodeficiency." New England Journal of Medicine 348(3): 255-256.

Haensler, J. and F. C. Szoka Jr (1993). "Polyamidoamine cascade polymers mediate efficient transfection of cells in culture." Bioconjugate chemistry 4(5): 372-379.

Hammond, S. M., S. Boettcher, et al. (2001). "Argonaute2, a link between genetic and biochemical analyses of RNAi." Science 293(5532): 1146.

Hannon, G. J. and J. J. Rossi (2004). "Unlocking the potential of the human genome with RNA interference." Nature 431(7006): 371-378.

Hashiba, T., M. Suzuki, et al. (2001). "Adenovirus-mediated transfer of heme oxygenase-1 cDNA attenuates severe lung injury induced by the influenza virus in mice." Gene Therapy 8(19): 1499.

Hassane, F. S., A. F. Saleh, et al. (2010). "Cell penetrating peptides: overview and applications to the delivery of oligonucleotides." Cellular and Molecular Life Sciences 67(5): 715-726.

Hellum, M., A. Høgset, et al. (2003). "Photochemically enhanced gene delivery with cationic lipid formulations." Photochemical \& Photobiological Science 2(4): 407-411.

Henry, T. D. and D. Satran (2012). "Therapeutic angiogenesis." Coronary Artery Disease: 67-74. 
Hirschberg, H., M. J. Zhang, et al. (2009). "Targeted delivery of bleomycin to the brain using photo-chemical internalization of Clostridium perfringens epsilon prototoxin." Journal of Neuro-Oncology 95(3): 317-329.

http://www.abedia.com/wiley/phases.php. date of access: 22/03/2012'

Hui, S. W., M. Langner, et al. (1996). "The role of helper lipids in cationic liposome-mediated gene transfer." Biophysical Journal 71(2): 590-599.

Johnson, L. A., R. A. Morgan, et al. (2009). "Gene therapy with human and mouse T-cell receptors mediates cancer regression and targets normal tissues expressing cognate antigen." Blood 114(3): 535-546.

Kaiser, P. K., R. C. Symons, et al. (2010). "RNAi-based treatment for neovascular age-related macular degeneration by Sirna-027." American journal of ophthalmology 150(1): 33-39

Kawabata, K., Y. Takakura, et al. (1995). "The fate of plasmid DNA after intravenous injection in mice: involvement of scavenger receptors in its hepatic uptake." Pharmaceutical Research 12(6): 825-830.

Ketting, R. F., S. E. J. Fischer, et al. (2001). "Dicer functions in RNA interference and in synthesis of small RNA involved in developmental timing in C. elegans." Genes $\mathcal{E}$ Development 15(20): 2654.

Khalil, I. A., K. Kogure, et al. (2006). "Uptake pathways and subsequent intracellular trafficking in nonviral gene delivery." Pharmacological Reviews 58(1): 32-45.

Kichler, A., C. Leborgne, et al. (2003). "Histidine-rich amphipathic peptide antibiotics promote efficient delivery of DNA into mammalian cells." Proceedings of the National Academy of Sciences 100(4): 1564.

Kichler, A., A. Mason, et al. (2006). "Cationic amphipathic histidine-rich peptides for gene delivery." Biochimica et Biophysica Acta (BBA)-Biomembranes 1758(3): 301-307.

Klink, D. T., S. Chao, et al. (2001). "Nuclear translocation of lactosylated poly-L-lysine/cDNA complex in cystic fibrosis airway epithelial cells." Molecular Therapy 3(6): 831-841.

Kloeckner, J., L. Prasmickaite, et al. (2004). "Photochemically enhanced gene delivery of EGF receptor-targeted DNA polyplexes." Journal of Drug Targeting 12(4): 205-213.

Konate, K., L. Crombez, et al. (2010). "Insight into the cellular uptake mechanism of a secondary amphipathic cell-penetrating peptide for siRNA delivery." Biochemistry 49(16): 3393-3402.

Kunath, K., A. von Harpe, et al. (2003). "Low-molecular-weight polyethylenimine as a nonviral vector for DNA delivery: comparison of physicochemical properties, transfection efficiency and in vivo distribution with high-molecular-weight polyethylenimine." Journal of Controlled Release 89(1): 113-125.

Kwon, E. J., J. M. Bergen, et al. (2008). "Application of an HIV gp41-derived peptide for enhanced intracellular trafficking of synthetic gene and siRNA delivery vehicles." Bioconjugate chemistry 19(4): 920-927.

Laga, R., R. Carlisle, et al. (2012). "Polymer coatings for delivery of nucleic acid therapeutics." Journal of Controlled Release (doi:10.1016/j.jconrel.2012.02.013).

Lam, J. K.-W., W. Liang, et al. (2012). "Pulmonary delivery of therapeutic siRNA." Advanced Drug Delivery Reviews 64(1): 1-15. 
Lam, J. K. W., W. Liang, et al. (2012). "Effective endogenous gene silencing mediated by pH responsive peptides proceeds via multiple pathways." Journal of Controlled Release 158(2): 293-303.

Leachman, S. A., R. P. Hickerson, et al. (2009). "First-in-human mutation-targeted siRNA phase Ib trial of an inherited skin disorder." Molecular Therapy 18(2): 442-446.

Lee, Y. J., G. Johnson, et al. (2011). "A HA2-Fusion tag limits the endosomal release of its protein cargo despite causing endosomal lysis." Biochimica et Biophysica Acta (BBA)General Subjects 1810: 752-758.

Legendre, J. Y. and F. C. Szoka Jr (1992). "Delivery of plasmid DNA into mammalian cell lines using $\mathrm{pH}$-sensitive liposomes: comparison with cationic liposomes." Pharmaceutical Research 9(10): 1235-1242.

Lehto, T., R. Abes, et al. (2010). "Delivery of nucleic acids with a stearylated (RxR)4 peptide using a non-covalent co-incubation strategy." Journal of Controlled Release 141(1): 42-51.

Li, W., F. Nicol, et al. (2004). "GALA: a designed synthetic pH-responsive amphipathic peptide with applications in drug and gene delivery." Advanced Drug Delivery Reviews 56(7): 967-985.

Lundberg, P., S. El-Andaloussi, et al. (2007). "Delivery of short interfering RNA using endosomolytic cell-penetrating peptides." The FASEB Journal 21(11): 2664-2671.

Lundin, P., H. Johansson, et al. (2008). "Distinct uptake routes of cell-penetrating peptide conjugates." Bioconjugate Chemistry 19(12): 2535-2542.

Luthman, H. and G. Magnusson (1983). "High efficiency polyoma DNA transfection of chloroquine treated cells." Nucleic Acids Research 11(5): 1295.

Mason, A. J., A. Martinez, et al. (2006). "The antibiotic and DNA-transfecting peptide LAH4 selectively associates with, and disorders, anionic lipids in mixed membranes." The FASEB Journal 20(2): 320-322.

Maurice-Duelli, A., A. Ndoye, et al. (2004). "Enhanced cell growth inhibition following PTEN nonviral gene transfer using polyethylenimine and photochemical internalization in endometrial cancer cells." Technology in Cancer Research \& Treatment 3(5): 459-465.

Maxfield, F. R. (1982). "Weak bases and ionophores rapidly and reversibly raise the $\mathrm{pH}$ of endocytic vesicles in cultured mouse fibroblasts." The Journal of Cell Biology 95(2): 676681.

Medina-Kauwe, L., J. Xie, et al. (2005). "Intracellular trafficking of nonviral vectors." Gene Therapy 12(24): 1734-1751.

Melikov, K. and L. Chernomordik (2005). "Arginine-rich cell penetrating peptides: from endosomal uptake to nuclear delivery." Cellular and Molecular Life Sciences 62(23): 27392749.

Mellman, I., R. Fuchs, et al. (1986). "Acidification of the endocytic and exocytic pathways." Annual Review of Biochemistry 55(1): 663-700.

Mello, C. C. and D. Conte (2004). "Revealing the world of RNA interference." Nature 431(7006): 338-342.

Merkel, O. M., A. Beyerle, et al. (2009). "Nonviral siRNA Delivery to the Lung: Investigation of PEG- PEI Polyplexes and Their In Vivo Performance." Molecular Pharmaceutics 6(4): 1246-1260. 
Midoux, P., A. Kichler, et al. (1998). "Membrane permeabilization and efficient gene transfer by a peptide containing several histidines." Bioconjugate Chemistry 9(2): 260-267.

Midoux, P., C. Mendes, et al. (1993). "Specific gene transfer mediated by lactosylated poly-Llysine into hepatoma cells." Nucleic Acids Research 21(4): 871-878.

Midoux, P. and M. Monsigny (1999). "Efficient gene transfer by histidylated polylysine/pDNA complexes." Bioconjugate Chemistry 10(3): 406-411.

Midoux, P., C. Pichon, et al. (2009). "Chemical vectors for gene delivery: a current review on polymers, peptides and lipids containing histidine or imidazole as nucleic acids carriers." British Journal of Pharmacology 157(2): 166-178.

Min, S. H., D. C. Lee, et al. (2006). "A composite gene delivery system consisting of polyethylenimine and an amphipathic peptide KALA." The Journal of Gene Medicine 8(12): 1425-1434.

Moan, J. and K. Berg (1991). "The photodegradation of porphyrins in cells can be used to estimate the lifetime of singlet oxygen." Photochemistry and Photobiology 53(4): 549-553.

Moreira, C., H. Oliveira, et al. (2009). "Improving chitosan-mediated gene transfer by the introduction of intracellular buffering moieties into the chitosan backbone." Acta Biomaterialia 5(8): 2995-3006.

Morille, M., C. Passirani, et al. (2008). "Progress in developing cationic vectors for non-viral systemic gene therapy against cancer." Biomaterials 29(24-25): 3477-3496.

Morris, M., P. Vidal, et al. (1997). "A new peptide vector for efficient delivery of oligonucleotides into mammalian cells." Nucleic Acids Research 25(14): 2730-2736.

Morris, M. C., L. Chaloin, et al. (2000). "Translocating peptides and proteins and their use for gene delivery." Current Opinion in Biotechnology 11(5): 461-466.

Morris, M. C., J. Depollier, et al. (2001). "A peptide carrier for the delivery of biologically active proteins into mammalian cells." Nature Biotechnology 19(12): 1173-1176.

Muratovska, A. and M. R. Eccles (2004). "Conjugate for efficient delivery of short interfering RNA (siRNA) into mammalian cells." FEBS letters 558(1-3): 63-68.

Navarro-Quiroga, I., J. Antonio González-Barrios, et al. (2002). "Improved neurotensinvector-mediated gene transfer by the coupling of hemagglutinin HA2 fusogenic peptide and Vp1 SV40 nuclear localization signal." Molecular Brain Research 105(1-2): 86-97.

Ndoye, A., G. Dolivet, et al. (2006). "Eradication of p53-mutated head and neck squamous cell carcinoma xenografts using nonviral p53 gene therapy and photochemical internalization." Molecular Therapy 13(6): 1156-1162.

Ndoye, A., J. L. Merlin, et al. (2004). "Enhanced gene transfer and cell death following p53 gene transfer using photochemical internalisation of glucosylated PEI-DNA complexes." The Journal of Gene Medicine 6(8): 884-894.

Niidome, T., N. Ohmori, et al. (1997). "Binding of cationic alpha-helical peptides to plasmid DNA and their gene transfer abilities into cells." Journal of Biological Chemistry 272(24): 15307-15312.

Niidome, T., K. Takaji, et al. (1999). "Chain length of cationic alpha-helical peptide sufficient for gene delivery into cells." Bioconjugate Chemistry 10(5): 773-780.

Nishiyama, N., A. Iriyama, et al. (2005). "Light-induced gene transfer from packaged DNA enveloped in a dendrimeric photosensitizer." Nature Materials 4(12): 934-941. 
Norum, O. J., J. V. Gaustad, et al. (2009). "Photochemical internalization of bleomycin is superior to photodynamic therapy due to the therapeutic effect in the tumor periphery." Photochemistry and Photobiology 85(3): 740-749.

Numata, K. and D. L. Kaplan (2010). "Silk-based gene carriers with cell membrane destabilizing peptides." Biomacromolecules 11: 3189-3195.

Oehlke, J., A. Scheller, et al. (1998). "Cellular uptake of an [alpha]-helical amphipathic model peptide with the potential to deliver polar compounds into the cell interior nonendocytically." Biochimica et Biophysica Acta (BBA)-Biomembranes 1414(1-2): 127-139.

Ohmori, N., T. Niidome, et al. (1998). "Importance of Hydrophobic Region in Amphiphilic Structures of $\alpha$-Helical Peptides for Their Gene Transfer-Ability into Cells." Biochemical and Biophysical Research Communications 245(1): 259-265.

Oliveira, S., M. M. Fretz, et al. (2007). "Photochemical internalization enhances silencing of epidermal growth factor receptor through improved endosomal escape of siRNA." Biochimica et Biophysica Acta (BBA) - Biomembranes 1768(5): 1211-1217.

Oliveira, S., A. Hogset, et al. (2008). "Delivery of siRNA to the target cell cytoplasm: photochemical internalization facilitates endosomal escape and improves silencing efficiency, in vitro and in vivo." Current Pharmaceutical Design 14(34): 3686-3697.

Pérez-Martínez, F., J. Guerra, et al. (2011). "Barriers to Non-Viral Vector-Mediated Gene Delivery in the Nervous System." Pharmaceutical Research 28(8): 1843-1858.

Pack, D. W., A. S. Hoffman, et al. (2005). "Design and development of polymers for gene delivery." Nature Reviews Drug Discovery 4(7): 581-593.

Pack, D. W., D. Putnam, et al. (2000). "Design of imidazole-containing endosomolytic biopolymers for gene delivery." Biotechnology and Bioengineering 67(2): 217-223.

Parente, R. A., S. Nir, et al. (1990). "Mechanism of leakage of phospholipid vesicle contents induced by the peptide GALA." Biochemistry 29(37): 8720-8728.

Patel, L. N., J. L. Zaro, et al. (2007). "Cell penetrating peptides: intracellular pathways and pharmaceutical perspectives." Pharmaceutical Research 24(11): 1977-1992.

Pathak, A., S. Patnaik, et al. (2009). "Recent trends in non-viral vector-mediated gene delivery." Biotechnology Journal 4(11): 1559-1572.

Pedroso de Lima, M. C., S. Simões, et al. (2001). "Cationic lipid-DNA complexes in gene delivery: from biophysics to biological applications." Advanced Drug Delivery Reviews 47(2-3): 277-294.

Pfeifer, C., G. Hasenpusch, et al. (2011). "Dry powder aerosols of polyethylenimine (PEI)based gene vectors mediate efficient gene delivery to the lung." Journal of Controlled Release 154(1): 69-76.

Pichon, C., I. Freulon, et al. (1997). "Cytosolic and nuclear delivery of oligonucleotides mediated by an amphiphilic anionic peptide." Antisense and Nucleic Acid Drug Development 7(4): 335-343.

Pichon, C., C. Gonçalves, et al. (2001). "Histidine-rich peptides and polymers for nucleic acids delivery." Advanced Drug Delivery Reviews 53(1): 75-94.

Pires, P., S. Simões, et al. (1999). "Interaction of cationic liposomes and their DNA complexes with monocytic leukemia cells." Biochimica et Biophysica Acta (BBA)-Biomembranes 1418(1): 71-84. 
Plank, C., B. Oberhauser, et al. (1994). "The influence of endosome-disruptive peptides on gene transfer using synthetic virus-like gene transfer systems." Journal of Biological Chemistry 269(17): 12918-12924.

Prasmickaite, L., A. Høgset, et al. (2000). "Role of endosomes in gene transfection mediated by photochemical internalisation (PCI)." The Journal of Gene Medicine 2(6): 477-488.

Raemdonck, K., B. Naeye, et al. (2009). "Biodegradable dextran nanogels for RNA interference: focusing on endosomal escape and intracellular siRNA delivery." Advanced Functional Materials 19(9): 1406-1415.

Raper, S. E., N. Chirmule, et al. (2003). "Fatal systemic inflammatory response syndrome in a ornithine transcarbamylase deficient patient following adenoviral gene transfer." Molecular Genetics and Metabolism 80(1-2): 148-158.

Remy, J. S., C. Sirlin, et al. (1994). "Gene transfer with a series of lipophilic DNA-binding molecules." Bioconjugate Chemistry 5(6): 647-654.

Richard, J. P., K. Melikov, et al. (2003). "Cell-penetrating peptides. A reevaluation of the mechanism of cellular uptake." Journal of Biological Chemistry 278(1): 585-590.

Rittner, K., A. Benavente, et al. (2002). "New basic membrane-destabilizing peptides for plasmid-based gene delivery in vitro and in vivo." Molecular Therapy 5(2): 104-114.

Sanders, N., C. Rudolph, et al. (2009). "Extracellular barriers in respiratory gene therapy." Advanced Drug Delivery Reviews 61(2): 115-127.

Sasaki, K., K. Kogure, et al. (2008). "An artificial virus-like nano carrier system: enhanced endosomal escape of nanoparticles via synergistic action of $\mathrm{pH}$-sensitive fusogenic peptide derivatives." Analytical and Bioanalytical Chemistry 391(8): 2717-2727.

Selbo, P. K., G. Sivam, et al. (2001). "In vivo documentation of photochemical internalization, a novel approach to site specific cancer therapy." International Journal of Cancer 92(5): 761-766.

Selbo, P. K., A. Weyergang, et al. (2010). "Photochemical internalization provides time- and space-controlled endolysosomal escape of therapeutic molecules." Journal of Controlled Release 148(1): 2-12.

Shieh, M. J., C. L. Peng, et al. (2008). "Non-toxic phototriggered gene transfection by PAMAM-porphyrin conjugates." Journal of Controlled Release 129(3): 200-206.

Shim, M. S. and Y. J. Kwon (2010). "Efficient and targeted delivery of siRNA in vivo." FEBS Journal 277: 4814-4827.

Simeoni, F., M. C. Morris, et al. (2003). "Insight into the mechanism of the peptide-based gene delivery system MPG: implications for delivery of siRNA into mammalian cells." Nucleic Acids Research 31(11): 2717-2724.

Simoes, S., V. Slepushkin, et al. (1999). "Mechanisms of gene transfer mediated by lipoplexes associated with targeting ligands or pH-sensitive peptides." Gene Therapy 6(11): 1798.

Sonawane, N. D., F. C. Szoka Jr, et al. (2003). "Chloride accumulation and swelling in endosomes enhances DNA transfer by polyamine-DNA polyplexes." Journal of Biological Chemistry 278(45): 44826-44831.

Stegmann, T. (2000). "Membrane fusion mechanisms: the influenza hemagglutinin paradigm and its implications for intracellular fusion." Traffic 1(8): 598-604. 
Stewart, D., J. Hilton, et al. (2006). "Angiogenic gene therapy in patients with nonrevascularizable ischemic heart disease: a phase 2 randomized, controlled trial of AdVEGF121 (AdVEGF121) versus maximum medical treatment." Gene Therapy 13(21): 1503-1511.

Sui, G., C. Soohoo, et al. (2002). "A DNA vector-based RNAi technology to suppress gene expression in mammalian cells." Proceedings of the National Academy of Sciences 99(8): 5515-5520.

Torchilin, V. P. (2008). "Tat peptide-mediated intracellular delivery of pharmaceutical nanocarriers." Advanced Drug Delivery Reviews 60(4): 548-558.

Urban-Klein, B., S. Werth, et al. (2004). "RNAi-mediated gene-targeting through systemic application of polyethylenimine (PEI)-complexed siRNA in vivo." Gene Therapy 12(5): 461-466.

van Rossenberg, S. M. W., K. M. Sliedregt-Bol, et al. (2002). "Targeted lysosome disruptive elements for improvement of parenchymal liver cell-specific gene delivery." Journal of Biological Chemistry 277(48): 45803-45810.

Veldhoen, S., S. D. Laufer, et al. (2006). "Cellular delivery of small interfering RNA by a noncovalently attached cell-penetrating peptide: quantitative analysis of uptake and biological effect." Nucleic Acids Research 34(22): 6561-6573.

Vinge, L. E., P. W. Raake, et al. (2008). "Gene therapy in heart failure." Circulation Research 102(12): 1458-1470.

Vivès, E., P. Brodin, et al. (1997). "A truncated HIV-1 Tat protein basic domain rapidly translocates through the plasma membrane and accumulates in the cell nucleus." Journal of Biological Chemistry 272(25): 16010-16017.

Vives, E. (2003). "Cellular utake of the Tat peptide: an endocytosis mechanism following ionic interactions." Journal of Molecular Recognition 16(5): 265-271.

Vlasov, G., E. Lesina, et al. (2005). "Optimization of transfection properties of DNA-lysine dendrimer complexes." Russian Journal of Bioorganic Chemistry 31(2): 153-159.

Vliegenthart, J., W. Knollen, et al. (1999). "Enhanced efficiency of lactosylated poly-L-lysinemediated gene transfer into cystic fibrosis airway epithelial cells." American Journal of Respiratory Cell and Molecular Biology 20(5): 1081-1086.

Vogt, T. C. B. and B. Bechinger (1999). "The interactions of histidine-containing amphipathic helical peptide antibiotics with lipid bilayers." Journal of Biological Chemistry 274(41): 29115.

Wagner, E. and J. Kloeckner (2006). "Gene delivery using polymer therapeutics." Polymer Therapeutics I: 135-173.

Wagner, E., C. Plank, et al. (1992). "Influenza virus hemagglutinin HA-2 N-terminal fusogenic peptides augment gene transfer by transferrin-polylysine-DNA complexes: toward a synthetic virus-like gene-transfer vehicle." Proceedings of the National Academy of Sciences 89(17): 7934-7938.

Wagner, E., K. Zatloukal, et al. (1992). "Coupling of adenovirus to transferrinpolylysine/DNA complexes greatly enhances receptor-mediated gene delivery and expression of transfected genes." Proceedings of the National Academy of Sciences 89(13): 6099-6103. 
Whitehead, K. A., R. Langer, et al. (2009). "Knocking down barriers: advances in siRNA delivery." Nature Reviews Drug Discovery 8(2): 129-138.

Wrobel, I. and D. Collins (1995). "Fusion of cationic liposomes with mammalian cells occurs after endocytosis." Biochimica et Biophysica Acta (BBA)-Biomembranes 1235(2): 296-304.

Wyman, T. B., F. Nicol, et al. (1997). "Design, synthesis, and characterization of a cationic peptide that binds to nucleic acids and permeabilizes bilayers." Biochemistry 36(10): 3008-3017.

Xu, Y. and F. C. Szoka Jr (1996). "Mechanism of DNA release from cationic liposome/DNA complexes used in cell transfection." Biochemistry 35(18): 5616-5623.

Yamamoto, M. and D. T. Curiel (2005). "Cancer gene therapy." Technology in Cancer Research $\mathcal{E}$ Treatment 4(4): 315-330.

Yang, S. R., H. J. Lee, et al. (2006). "Histidine-conjugated poly (amino acid) derivatives for the novel endosomolytic delivery carrier of doxorubicin." Journal of Controlled Release 114(1): 60-68.

Yip, W. L., A. Weyergang, et al. (2007). "Targeted delivery and enhanced cytotoxicity of cetuximab-saporin by photochemical internalization in EGFR-positive cancer cells." Molecular Pharmaceutics 4(2): 241-251.

Yu, M., E. Poeschla, et al. (1994). "Progress towards gene therapy for HIV infection." Gene Therapy 1(1): 13-26.

Zabner, J., A. J. Fasbender, et al. (1995). "Cellular and molecular barriers to gene transfer by a cationic lipid." Journal of Biological Chemistry 270(32): 18997-19007.

Zelphati, O. and F. C. Szoka (1996). "Intracellular distribution and mechanism of delivery of oligonucleotides mediated by cationic lipids." Pharmaceutical Research 13(9): 1367-1372.

Zelphati, O. and F. C. Szoka (1996). "Mechanism of oligonucleotide release from cationic liposomes." Proceedings of the National Academy of Sciences 93(21): 11493.

Zhou, J., J. Wu, et al. (2006). "PAMAM dendrimers for efficient siRNA delivery and potent gene silencing." Chemical Communications(22): 2362-2364.

Zhou, X. and L. Huang (1994). "DNA transfection mediated by cationic liposomes containing lipopolylysine: characterization and mechanism of action." Biochimica et Biophysica Acta (BBA)-Biomembranes 1189(2): 195-203.

Zuhorn, I. S., U. Bakowsky, et al. (2005). "Nonbilayer phase of lipoplex-membrane mixture determines endosomal escape of genetic cargo and transfection efficiency." Molecular Therapy 11(5): 801-810. 